Jurnal Pemberdayaan: Publikasi Hasil Pengabdian kepada Masyarakat

Vol. 2, No. 1, April 2018, Hal. 59-64

ISSN: 2088 4559; e-ISSN: XXXX-XXXX

DOI:

\title{
Peningkatan Perilaku Sehat pada Siswa Sekolah Dasar melalui PHBS di Desa Gondanglegi dan Pucangan, Kecamatan Ambal, Kabupaten Kebumen
}

\author{
Erni Gustina $^{1}$, Fakhri Abdussalam, Wawan Saputra ${ }^{3}$ \\ Fakultas kesehatan masyaraka, Universitas Ahmad Dahlan ${ }^{1}$ \\ Mahasiswa Universitas Ahmad Dahlan ${ }^{2,3}$ \\ Email: erni.gustina@ikm.uad.ac.id ${ }^{1}$
}

\begin{abstract}
ABSTRAK
Anak merupakan aset terpenting dalam tercapainya keberhasilan suatu negara, karena anaknya merupakan generasi penerus bangsa. Anak usia sekolah merupakan kelompok usia yang kritis karena pada usia tersebut rentan terhadap masalah kesehatan. Masalah kesehatan umum yang terjadi pada anak usia sekolah biasanya berkaitan dengan kebersihan perorangan dan lingkungan seperti gosok gigi yang baik dan benar, kebersihan diri, serta kebiasaan cuci tangan pakai sabun, serta membersihkan kuku dan rambut. Peningkatan pemahaman siswa tentang cuci tangan dan menggosok gigi diberikan menggunakan metode pelatihan yaitu memberikan pengetahuan dan praktik terkait cuci tangan dan menggosok gigi. Hasil yang diperoleh adalah kegiatan pelatihan berjalan dengan baik dan siswa aktif bertanya dan antusias dalam mepraktikkan angkah-langkah cuci tangan dengan menggunakan sabun dan air mengalir dan meggosok gigi degan baik dan benar.
\end{abstract}

Kata kunci : Cuci tangan, Menggosok gigi, Anak

\section{ABSTRACT}

Childrens are the most important asset in achieving the success of a country, because their children are the next generation of the nation. School-age children are a critical age group because at that age they are vulnerable to health problems. General health problems that occur in school-age children are usually related to personal hygiene and the environment such as good and correct brushing, personal hygiene, and hand washing habits with soap, and cleaning nails and hair. Increasing student's understanding of hand washing and tooth brushing is given using training methods that are providing knowledge and practice regarding hand washing and brushing teeth. The results obtained were that the training activities went well and the students actively asked and were enthusiastic in practicing the steps to wash their hands using soap and running water and brushing their teeth properly and correctly

Keywords: washing hands, brushing teeth, child

\section{PENDAHULUAN}

Perilaku adalah kegiatan yang dilakukan oleh seseorang, baik yang dapat diamati secara langsung maupun tidak langsung. Sedangkan sehat adalah suatu kondisi yang baik, yang mencakup fisik, mental, dan sosial, tidak hanya terbebas dari penyakit dan kecacatan. Sedangkan perilaku sehat adalah tindakan seseorang atau kegiatan yang dilakukan oleh seseorang, baik langsung maupun tidak langsung, untuk mempertahankan dan meningkatkan 
kesehatannya serta mencegah risiko penyakit (Kementerian Pendidikan, 2011). Meningkatkan perilaku sehat pada anak salah satu contohnya adalah membiasakan hidup bersih dan sehat.

Perilaku hidup bersih dan sehat (PHBS) adalah semua perilaku kesehatan yang dilakukan karena kesadaran pribadi sebagai hasil pembelajaran sehingga keluarga dan seluruh anggotanya mampu menolong diri sendiri pada bidang kesehatan serta memiliki peran aktif dalam aktivitas masyarakat (Permenkes, 2011). Perilaku hidup bersih sehat pada dasarnya merupakan sebuah upaya untuk menularkan pengalaman mengenai pola hidup sehat melalui individu, kelompok ataupun masyarakat luas dengan jalur - jalur komunikasi sebagai media berbagi informasi. Ada berbagai informasi yang dapat dibagikan seperti materi edukasi guna menambah pengetahuan serta meningkatkan sikap dan perilaku terkait cara hidup yang bersih dan sehat. Perilaku hidup sehat dan sehat pada tatanan sekolah ialah praktik kebiasaan hidup bersih dan sehat dalam kehidupan sehari-hari baik selama siswa berada di kelas maupun di luar kelas seperti siswa melakukan cuci tangan dengan sabun, melakukan sosok gigi secara teratur.

Anak merupakan aset terpenting dalam tercapainya keberhasilan suatu negara, karena anaknya merupakan generasi penerus bangsa. Derajat kesehatan anak belum bisa dikatakan baik karena masih banyak terdapat masalah kesehatan khususnya pada anak sekolah. Anak usia sekolah merupakan kelompok usia yang kritis karena pada usia tersebut rentan terhadap masalah kesehatan. Masalah kesehatan yang sering timbul pada usia anak sekolah yaitu gangguan perilaku, gangguan perkembangan fisiologis hingga gangguan dalam belajar dan juga masalah kesehatan umum. Berbagai macam masalah yang muncul pada anak usia sekolah, namun masalah yang biasanya terjadi yaitu masalah kesehatan umum. Masalah kesehatan umum yang terjadi pada anak usia sekolah biasanya berkaitan dengan kebersihan perorangan dan lingkungan seperti gosok gigi yang baik dan benar, kebersihan diri, serta kebiasaan cuci tangan pakai sabun, serta membersihkan kuku dan rambut.

\section{METODE}

Peningkatan perilaku sehatan pada anak SD menggunakan metode pendekatan pelatihan, pendampingan dan penyediaan alat dan bahan seperti sabun untuk cuci tangan cuci tangan dan paket menggosok gigi. Pelathan kesehatan ini dimulai dengan memberikan pengetahuan cuci tangan dan menggosok gigi kepada anak-anak yang baik dan benar serta pemutaran film serta praktik cuci tangan dan menggosok gigi Setelah kegiatan pelatihan dilakukan, diadakan monitoring dan evaluasi untuk memastikan kegiatan berjalan dengan baik dan lancar. 


\section{HASIL, PEMBAHASAN, DAN DAMPAK}

Kegiatan pelatihan ini dilakukan pada bulan Agustus 2018 ini bertempat di gedung Sekolah Dasar. Peserta pada kegiatan ini adalah anak-anak sekolah dasar yang ada di desa Gondanglegi dan desa Pucangan kecamatan Ambal, Kabupaten Kebumen. Berikut adalah foto kegiatan pelatihan PHBS pada anak SD di Desa Gondanglegi dan Desa Pucangan, Kec. Ambal, Kab, Kebumen, Jawa Tengah.
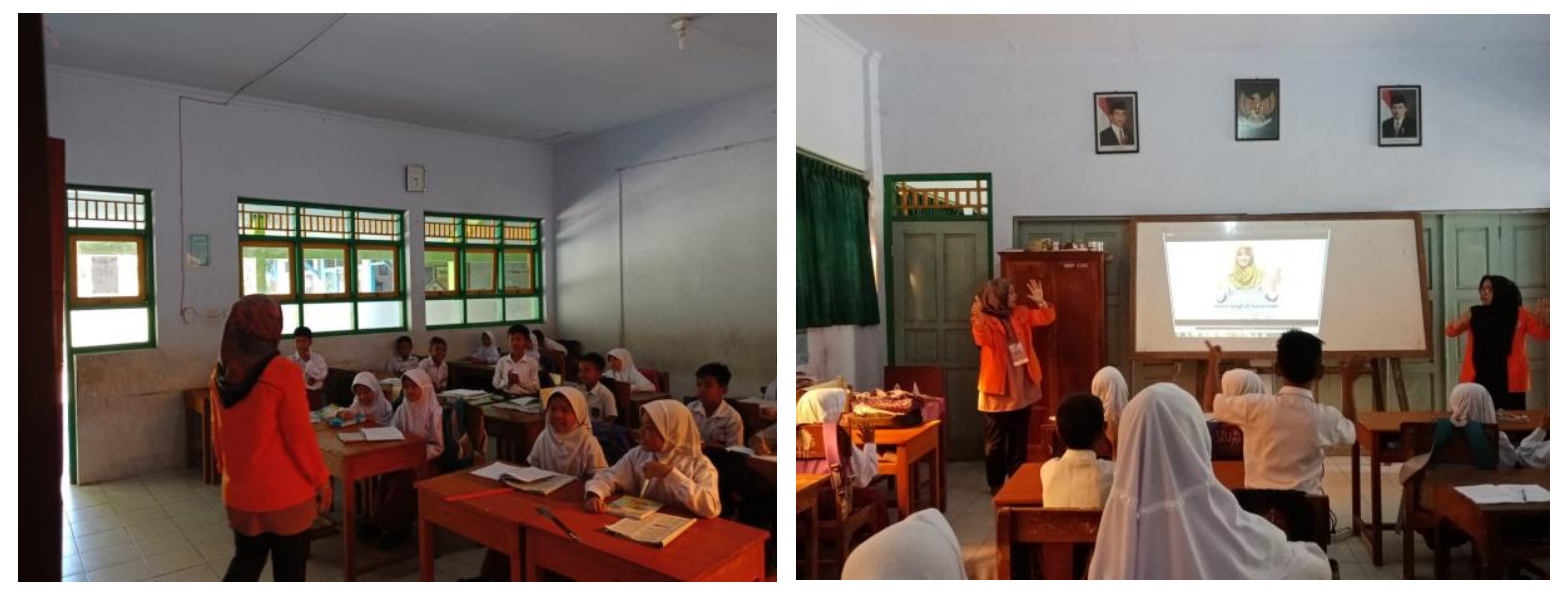

Gambar 1. Pemberian materi tentang cuci tangan dan menggosok gigi pada anak Sekolah Dasar di Desa Gondanglegi dan Desa Pucangan

Materi yang diberikan adalah materi penyuluhan tentang cuci tangan pakai sabun dan menggosok gigi serta pemutaran film tentang langkah-langkah cuci tangan dengan sabun dan air mengalir dan menggosok gigi dengan baik dan benar. Setelah materi diberikan, siswa diminta menjelaskan kembali materi yang telah diberikan. Pemberian materi ini diharapkan memberikan pemahaman kepada siswa sekolah dasar tentang pentingnya cuci tangan menggunakan sabun dan air mengalir sebelum dan sesudah melakukan aktivitas, seperti cuci tangan sebelum dan sesudah makan. 

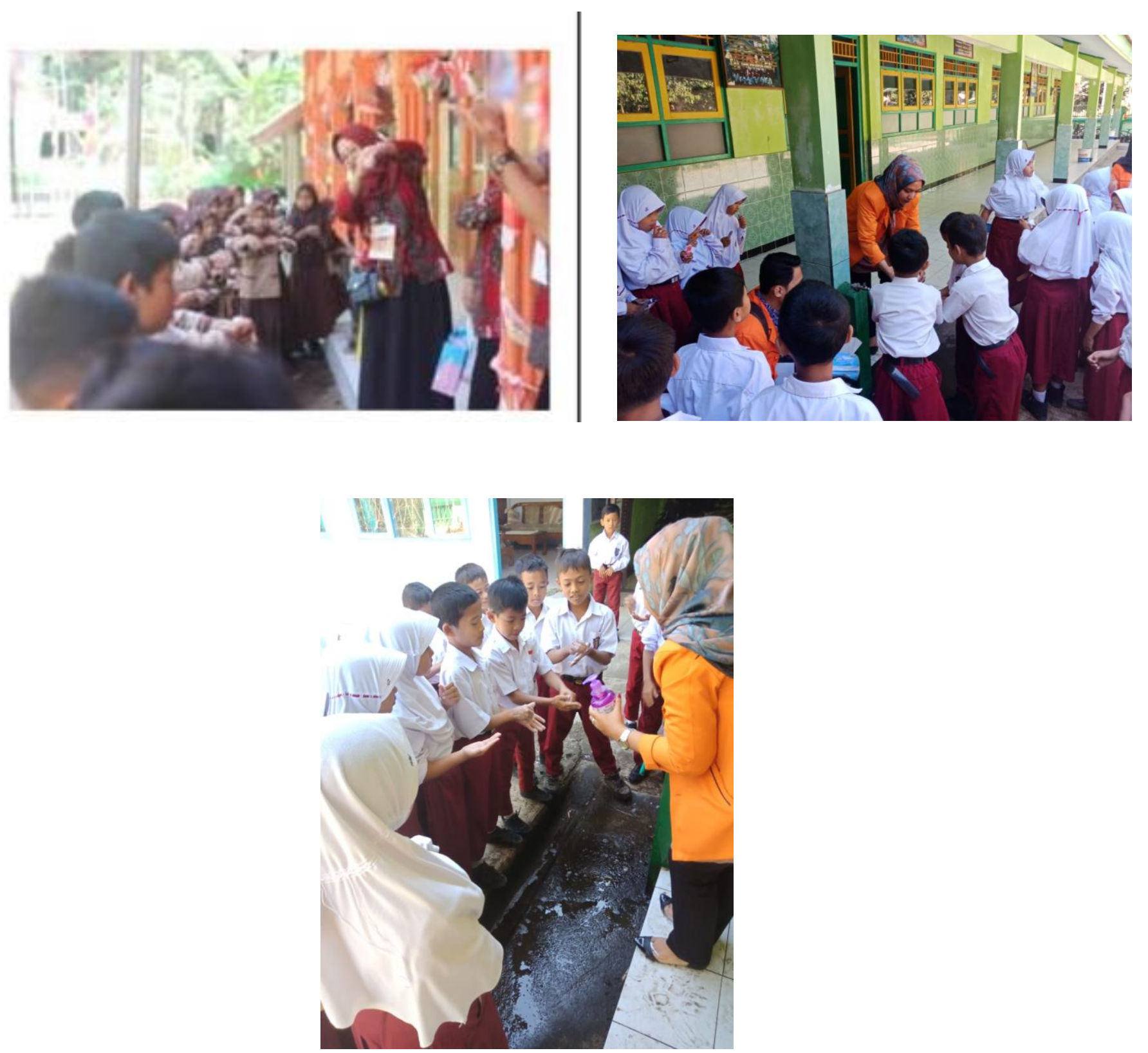

Gambar 2. Praktik mencuci tangan dengan 7 langkah menggunakan sabun dan air mengalir

Mencuci tangan dengan sabun dan air mengalir adalah hal wajib yang harus kamu lakukan untuk menjaga kesehatan tubuh. Terkadang, mencuci tangan dianggap merupaka hal yang sepele. Kebanyakan orang hanya menggosok tangan dengan air tanpa menggunakan sabun. Hal ini menyebabkan kuman masih banyak yang menempel. Kuman dan virus dapat bertahan hidup hingga 2 jam di atas permukaan kulit, meja, gagang pintu, mainan, dan lainlain. Kebersihan tangan yang tidak terpelihara dengan baik dapat menyebabkan penyakit seperti diare, batuk, pilek, dan demam. Agar kebersihan tangan tetap terjaga, anak sebaiknya mencuci tangan dnegan menggunakan sabun dan air mengalir sebelum dan sesudah melakukan 
aktivitas baik di dalam rumah maupun di luar rumah, misal mencuci tangan sebelum dan sesudah makan.

\section{SIMPULAN}

Kegiatan pelatihan cuci tangan dan menggosok gigi di di desa Gondanglegi dan Desa Pucangan dapat berjalan dengan baik dan lancar. Siswa antusias dan dapat bekerjasama dengan baik, serta dapat mempraktikkan mencucui tangan dengan sabun dan air mengalir serta dapat mempraktikkan menggosok gigi dengan baik dan benar.

\section{DAFTAR PUSTAKA}

Kementerian Pendidikan Indonesia. 2011. Mengembangkan perilaku sehat pada naka usia 24 tahun. Direktorat Pembinaan Pendidikan Anak Usia Dini. Jakarta

Peraturan menteri Kesehatan Republik Indonesia. 2011. Pedoman pembinaan perilaku hidup bersih dan sehat (PHBS). Jakarta

\section{UCAPAN TERIMAKASIH}

Terima kasih diucapkan kepada:

1. Universitas Ahmad Dahlan sebagai penyumbang dana kegiatan pelatihan ini.

2. Pemerintah Desa Gondanglegi dan Desa Pucangan yang memberikan dukungan dalam pelaksanaan kegiatan pelatihan ini.

3. Kepala Sekolah SDN Desa Gondanglegi dan desa Pucangan yang telah memberikan kesemppatan kepada tim pelaksanak untuk memberikan pendidikan kesehatan kepada siswa sekolah Dasar di Sekolah yang dipimpin. 
2018 Jurnal Pemberdayaan: Publikasi Hasil Pengabdian kepada Masyarakat - ISSN: 2088 4559; e-ISSN:

Peningkatan Perilaku Sehat pada Siswa Sekolah Dasar melalui PHBS (Erni Gustina) | 64 